\title{
EFFECT OF TEMPERATURE AND PH ON PHENOL BIODEGRADATION BY A NEWLY IDENTIFIED SERRATIA SP. AQ5-03
}

\author{
${ }^{* 1,2}$ Aisami, A., ${ }^{1}$ Yasid, N. A., ${ }^{3}$ Johari, W. L. W., ${ }^{1}$ Ahmad, S. A. and ${ }^{1}$ Shukor, M. Y.
}

\begin{abstract}
${ }^{1}$ Department of Biochemistry, Faculty of Biotechnology and Biomolecular Sciences, University Putra Malaysia, Selangor, Malaysia.
${ }^{2}$ Department of Biochemistry, Gombe State University, P.M.B. 127, Tudun Wada, Gombe, Gombe State, Nigeria.

${ }^{3}$ Department of Environmental Sciences, Faculty of Environmental Studies, University Putra Malaysia, 43400 UPM Serdang, Selangor, Malaysia

*Phone: +2348067750526*Email: abubakar.aisami05@gmail.com
\end{abstract}

\begin{abstract}
Phenol is mainly used by the industries to produce a variety of chemical products such as resins, textiles, pesticides, plastics and explosive. The wide use of phenol and other phenolic compounds by industries, has resulted in an increased presence of these toxic compounds in the environment as pollutants. Bio-removal of phenol by microorganisms especially bacteria has been demonstrated to be the most effective and economical approach compared to physio-chemical methods. The search for efficient phenol-degraders especially local sources to remediate local phenol pollution is important as indigenous bacteria usually have better survival and resilient to local geographical conditions. In this study, a phenol-degrading microorganism was isolated from local soil and waste water bodies. Identification was carried out using gram staining, 16s rRNA gene sequencing and molecular phylogeny analysis using the Phylip software. The isolates were inoculated in mineral salt media with $0.5 \mathrm{~g} / \mathrm{L}$ phenol as the sole source of carbon. Phenol degradation was determined using 4-amino antipyrine method. Physical and cultural conditions influencing phenol degradation such as $\mathrm{pH}$ and temperature were optimized via one-factor-at-a-time. Through phylogeny analysis, the isolate was identified as Serratia sp. and the sequence was deposited the NCBI Genebank and accession number KT693287 was assigned to the bacteria. The highest degradation was achieved at $\mathrm{pH} 7.5$ (phosphate buffer) and temperature of $30^{\circ} \mathrm{C}$. Ammonium sulphate was established to be the best nitrogen source at the concentration of $0.4 \mathrm{~g} / \mathrm{L}$ and a sodium chloride concentration of $0.15 \mathrm{~g} / \mathrm{L}$.
\end{abstract}

Keywords: bio-removal, $\mathrm{pH}$, temperature phylogeny, phenol, $16 \mathrm{~s}$ rRNA

LICENSE: This work by Open Journals Nigeria is licensed and published under the Creative Commons Attribution License 4.0 International License, which permits unrestricted use, distribution, and reproduction in any medium, provided this article is duly cited.

COPYRIGHT: The Author(s) completely retain the copyright of this published article.

OPEN ACCESS: The Author(s) approves that this article remains permanently online in the open access (OA) mode.

QA: This Article is published in line with "COPE (Committee on Publication Ethics) and PIE (Publication Integrity \& Ethics)". 


\section{INTRODUCTION}

Environmental pollution is one of the major concerns in the $21^{\text {st }}$ century; where billions of tonnes of harmful chemicals are produced by industries such as petroleum, paints, food, rubber, and plastic. These toxicants finds their ways into the environment through air, soil, and water. Combustion of fuel, burning activities and power stations are the major sources of air pollution where volatile hydrocarbons are released into the air (DOE, 2009). Air pollutions can lead to many respiratory, cardiovascular and liver diseases (Brook et al., 2004; Ko and Hui, 2010). The discharge of untreated harmful compounds and heavy metals are the primary sources of water and soil pollution. In addition, oil spillage from petroleum industries contributes significantly to the global incidence of soil and water pollutions (Hossain, et al., 2009).

Among the phenolic compounds, phenol is the most commonly used by industries and is the precursor for the synthesis of many industrial chemicals. Plastic, coke and petroleum industries produce the highest effluents containing phenol (up to $7 \mathrm{~g} / \mathrm{L}$ ). (Luo et al., 2009; Luo et al., 2011; Maheshwari and Gupta, 2016). Oil spills, deck overspill leakages from vessels, pipelines and storage tanks and offshore disposal of waste are also major sources of water pollution (Aghalino and Eyinla, 2009; Matkin, et al., 2008). These industrial waste are treated with physiochemical methods. However, physiochemical methods alone are not efficient due to its high cost and also the generation of secondary pollutions (González, et al., 2006; Suhaila, et al., 2013b). The existence of these microorganisms can be used for the biodegradation of phenol and other phenolic compounds.

Bioremediation as an alternative method to physicochemical methods is a very cost-effective method, and an environmentally friendly way of controlling pollutions (Ali, et al., 2009; Desai, et al., 2010). To optimise the bioremediation ability of microorganisms to biodegrade phenol, an appropriate inoculum size, $\mathrm{pH}$ and temperature are crucial factors (Pradeep et al., 2015).

Although a lot of research has been carried out on the degradation of phenol by microorganisms yet there is need for identifying more organisms that are capable of degrading phenols. To date, there are very few locally-isolated phenol-degrading microorganisms (Ahmad et al., 2011; Fereidoun, et al., 2007). There is a need to increase the reservoir of a phenol-degrading microorganism to prepare for phenol remediation in the current and future scenario.

\section{MATERIAL AND METHODS CHEMICALS, REAGENTS, AND EQUIPMENT}

All the chemicals, reagents, and equipment used in this study are listed in Appendix I.The chemicals and reagents are of analytical grades.

\section{BACTERIAL SAMPLING AND SCREENING}

Soil and wastewater samples were obtained from industrial areas from industrial areas in Selangor Johor, Kedah, Sarawak, and Melaka in Malaysia. The samples were kept in a $50 \mathrm{~mL}$ propylene centrifuge tubes in ice $\left(0^{\circ} \mathrm{C}\right)$ while being transported to the laboratory. The samples were stored in a $-20^{\circ} \mathrm{C}$ freezer until required for use. The phenoldegrading bacteria were isolated based on their growth on mineral salt media with $0.5 \mathrm{~g} / \mathrm{L}$ phenol as the sole source of carbon and incubated at $27^{\circ} \mathrm{C}$ with constant shaking at $180 \mathrm{rpm}$ for 24 hours (Bai et al., 2007). 


\section{MAINTENANCE OF THE ISOLATES}

The isolates were sustained on nutrient agar slant culture at $4{ }^{\circ} \mathrm{C}$ for routine use and in glycerol stock at $-20{ }^{\circ} \mathrm{C}$ for long-term storage.

\section{GRAM STAINING}

A light suspension of cells from 24 hour nutrient broth culture was prepared. A drop of the cell suspension was added to a clean glass slide and spread with a loop over the slide surface and allowed to air dry. The slide was covered with methanol and allowed to evaporate at room temperature. Heat-fixed smear slides were placed on staining tray and were gently flooded with crystal violet and allowed to stand for 1 minute. The slide was then tilted slightly and gently rinsed with distilled water using a wash bottle, then gently flooded with Gram's iodine and allowed to stand for 1 minute. The smeared slides were slightly and gently rinsed with distilled water using a wash bottle. The smear appeared as a purple circle on the slide. It was then decolourised using $95 \%$ ethyl alcohol applying the alcohol dropwise for 10 seconds and rinsed immediately with distilled water. It was then gently flooded with safranin to counter-stain and allowed for 1 minute and rinsed with distilled water. It was viewed under an under oil immersion microscope.

\section{ANALYTICAL METHOD}

Phenol degradation was determined using 4-amino antipyrine, a colourimetric assay based on the reaction of the reagent with phenol in the presence of potassium ferric cyanide under alkaline $\mathrm{pH}$. The absorbance was read at 510 nm (Arif, et al., 2013).

\section{MINERAL SALT MEDIA}

$\mathrm{K}_{2} \mathrm{HPO}_{4}(400 \mathrm{mg} / \mathrm{L}), \mathrm{KH}_{2} \mathrm{PO}_{4} \quad(200 \mathrm{mg} / \mathrm{L}), \mathrm{MgSO}_{4},(100 \mathrm{mg}), \mathrm{Fe}_{2}\left(\mathrm{SO}_{4}\right) \cdot \mathrm{H}_{2} \mathrm{O}(10 \mathrm{mg} / \mathrm{L}), \mathrm{NaCl}(100 \mathrm{mg} / \mathrm{L})$, $\mathrm{NaMoO}_{4} \cdot 2 \mathrm{H}_{2} \mathrm{O}(10 \mathrm{mg} / \mathrm{L}), \mathrm{MnSO}_{4} \cdot 2 \mathrm{H}_{2} \mathrm{O}(10 \mathrm{mg} / \mathrm{L})$ and $\left(\mathrm{NH}_{4}\right)_{2} \mathrm{SO}_{4}$ were dissolved in $1 \mathrm{~L}$ of distilled water, and the $\mathrm{pH}$ adjusted to 7.2 before autoclaving at $121^{\circ} \mathrm{C}$ for $15 \mathrm{~min}$. Phenol to the final concentration of $500 \mathrm{mg} / \mathrm{L}$ was introduced as the only source of carbon before use.

\section{PROCEDURE FOR 4-AMINOANTYPRINE ASSAY}

Sample $(1.5 \mathrm{ml})$ was first centrifuged for 15 minutes at $10,000 \times g$ and the supernatant was collected. One hundred $\mu \mathrm{L}$ each of 4- amino antipyrine and potassium ferric cyanide solutions were added to the $1 \mathrm{~mL}$ of the supernatant, and the $\mathrm{pH}$ was adjusted to $10 \mathrm{using} 1 \mathrm{M} \mathrm{NaOH}$. The mixture was incubated at room temperature for 15 minutes, and the absorbance was read against the blank at $510 \mathrm{~nm}$ using a spectrophotometer.

\section{MOIECULAR IDENTIFICATION OF THE ISOLATE GENOMIC DNA EXTRACTION}

The genomic DNA was extracted using bacterial DNA extraction protocol according to the manufacturers' (Thermo Scientific GeneJet Genomic DNA Extraction) instruction. Pellets from a $24 \mathrm{~h}$ old nutrient broth bacterial cells were 
utilised for the extraction. The cells were harvested by centrifugation at $10000 \times g$ for $10 \mathrm{~min}$, and then $180 \mu \mathrm{L}$ of digestion solution was added followed by $20 \mu \mathrm{L}$ proteinase $\mathrm{K}$ solution and mixed exhaustively by vortexing until a homogenous solution was obtained. The resultant solution was then incubated at $56^{\circ} \mathrm{C}$ in a water bath for 1 min for the cells to lyse entirely. RNase A solution $(20 \mu \mathrm{L})$ was added and mixed thoroughly and incubated at room temperature for $10 \mathrm{~min}$. Then, $200 \mu \mathrm{L}$ of lysis solution was then added to the mixture and was mixed thoroughly using a vortex mixer to attain homogeneity. By pipetting, $400 \mu \mathrm{L}$ of ethanol (50\%) was added and mixed. The sample was then transferred into the GeneJet genomic DNA purification column with a collection tube and centrifuged for $1 \mathrm{~min}$ at $6000 \times g$. The flow-through solution and the collection tube was discarded. Into a new tube, the GeneJet genomic DNA purification column was positioned and $500 \mu \mathrm{L}$ of wash buffer I was introduced and centrifuged for 1 min at $8000 \times g$ followed by the addition of $500 \mu \mathrm{L}$ of wash buffer II to the column and centrifuged for $3 \mathrm{~min}$. The step was repeated to get maximum yield. The collection tube was discarded, which contained the flowthrough of the solution. The GeneJet genomic DNA purification column was transferred into a $1.5 \mathrm{~mL}$ sterile microcentrifuge tube. Elution buffer $(200 \mu \mathrm{L})$ was pipetted at the centre of the GeneJet genomic DNA purification column membrane and incubated at room temperature for $2 \mathrm{~min}$ and centrifuged at $8000 \times g$ for $1 \mathrm{~min}$ to elute the DNA. The purification column was discarded and the DNA collected in a $1.5 \mathrm{ml}$ centrifuge tube. The DNA was stored at $-20^{\circ} \mathrm{C}$ and $10 \mu \mathrm{L}$ of DNA was loaded onto a $1 \%(\mathrm{v} / \mathrm{v})$ agarose gel electrophoresis using $\lambda$ HindIII DNA marker (Fermentas, USA) as a template for the polymerase chain reaction (PCR).

\section{POLYMERASE CHAIN REACTION}

Biometra T-Gradient Thermocycler was used for conducting the PCR. The Universal primers: 27F: 5'-AGA GTT TGA TCC TGG CTC AG-3' forward and 1492R: 5'-TAC GGT TAC CTT GTT ACG ACT T-3', reverse were used for the polymerase chain reaction (PCR) with Genomic DNA as the template ( Karamba et al., 2015). The $25 \mu \mathrm{L}$ PCR mixture composed of $1 \mu \mathrm{L}$ forward primer, $1 \mu \mathrm{L}$ reverse primer, $1 \mu \mathrm{L}$ DNA template, $9.5 \mu \mathrm{L}$ master mix, $12.5 \mu \mathrm{L}$ deionized water and $1 \mu \mathrm{L}$ of the reverse and forward primers of $16 \mathrm{~S}$ rRNA, respectively. The polymerase chain reaction (PCR) was carried out under the following conditions: 1 cycle of initial denaturation at $96^{\circ} \mathrm{C}$ for $4 \mathrm{~min} ; 30$ cycles $\left(94^{\circ} \mathrm{C}\right.$ denaturing for $1 \mathrm{~min}, 52.3^{\circ} \mathrm{C}$ annealing for $1 \mathrm{~min}, 72^{\circ} \mathrm{C}$ extension for $1 \mathrm{~min}$ ) and one cycle of final extension at $72^{\circ} \mathrm{C}$ for $7 \mathrm{~min}$. Preservation was done at $10^{\circ} \mathrm{C}$. The presence of the amplified $16 \mathrm{~S}$ rRNA was confirmed by using $1.0 \%$ agarose gel electrophoresis (Fermentas, USA) and was viewed with UV transilluminator (UPV, USA).

\section{SEQUENCE ANALYSIS}

The amplified DNA was sent for sequencing at MyTACG Bioscience Laboratories SDN BHD. The sequences were edited using MEGA version 6 and aligned for homology by the use of BLAST 2 (Basic Local Alignment System Tool) sequences.

\section{PHYLOGENETIC TREE ANALYSIS AND EVOLUTIONARY RELATIONSHIPS OF TAXA}

Phylogenetic trees were constructed using the PHYLIP suite of programs (Felsenstein, 1992). The program DNADIST was used to compute the evolutionary distance in the neighbour-joining method (Saitou and Nei, 1987). The distance 
matrixes were written as an output file. SEQBOOT component checked and analysed the confidence levels of branches within the trees in the PHYLIP package, and 1000 bootstraps were used (Felsenstein, 1985). A CONSENSE program was used to construct the consensus tree for the topologies (Margush and McMorris, 1981). The TreeView program was used to view the tree (Page, 1996). Four models for base substitution were used; (Jukes and Cantor, 1969), Kimura (Kimura, 1980), F84 model (Felsenstein, 1992; Kishino and Hasegawa, 1989) and LogDet distance (Lockhart, et al., 1994).

\section{EFFECT OF PH AND TEMPERATURE}

The preceding literature on biodegradation studies reported that bacteria have a preference of $\mathrm{pH}$ ranges of 6.5 to 7.5 for both bacterial growth and biodegradation rates (Demoling and Bååth, 2008). pH ranging from 4 to 9 was selected for this research. The buffers used were acetate buffer from $\mathrm{pH} 4$ to 6 , phosphate buffer from $\mathrm{pH} 6$ to 7.5 and Tris$\mathrm{HCl}$ buffer ( $\mathrm{pH} 7$ to 9). Temperature has being shown to be among the most vital factors in bioremediation (Margesin, et al., 2005). In this study, temperatures ranging from 15 to $45^{\circ} \mathrm{C}$ with an interval of $5{ }^{\circ} \mathrm{C}$ was used to determine its effect on both the bacterial growth and phenol degradation rates.

\section{STATISTICAL ANALYSIS}

All conducted experiments were carried out in triplicates. Experimental errors were shown in Error bars in all graphs represented as standard errors (SE) from three determinations. All data were analyzed using GraphPad Prism 5. A one-way ANOVA (95\% confidence interval) and t-test (LSD) for biodegradation were utilised to evaluate the differences among parameters and $\mathrm{p}<0.05$ is deemed statistically significant.

\section{RESULTS}

\section{GRAM STAINING OF ISOLATE AQ5-03}

Figure 1 shows the gram staining result of isolate AQ5-03. The bacterial cell was pink in colour, demonstrating a characteristic of Gram-negative. It is rod-shaped, motile through flagella and occurs in sets. The microscopic analysis exemplifies that the colony is creamy white. 


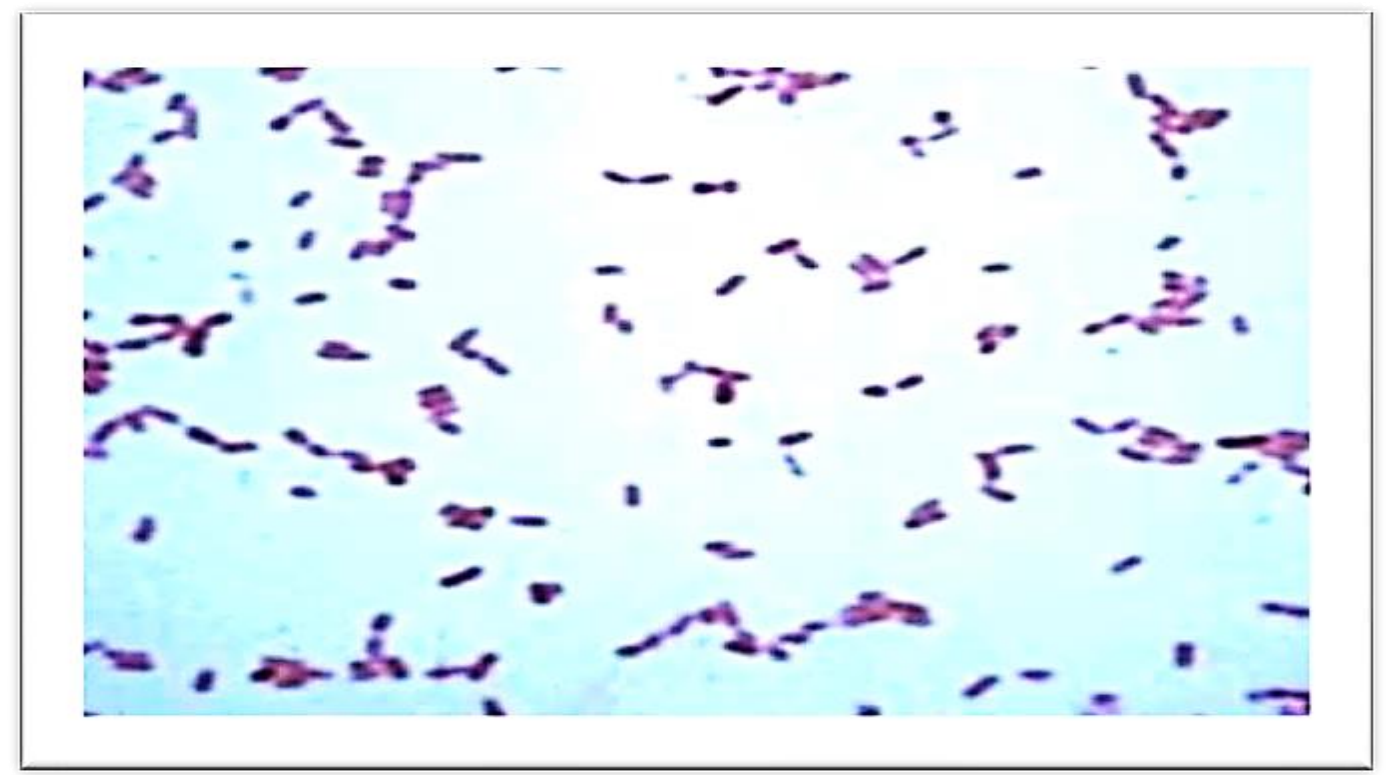

Figure 1: Gram stain smear of isolate AQ5-03 under 1000 x magnification on a light microscope.

\section{GENOMIC DNA EXTRACTION}

Genomic DNA of the isolate was successfully extracted. Clear bands with high intensity for the bacteria were obtained and was estimated at $23130 \mathrm{bp}$, which is an indication of good quality DNA concentration and were further used as the templates for the PCR (Zeng et al., 2008). A Hind III digest of lambda DNA was used as the marker for the agarose gel electrophoresis (Figure 2).

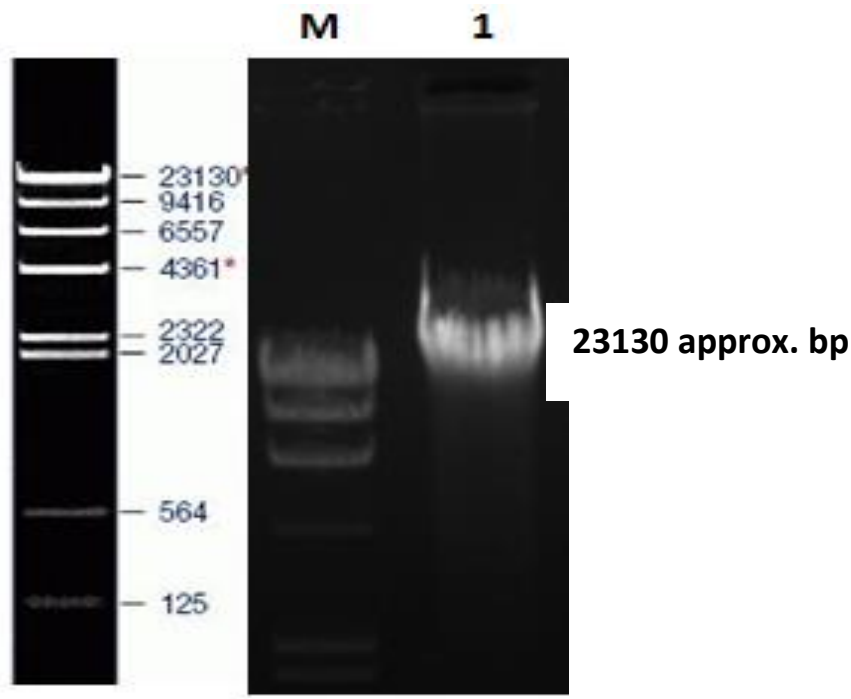

Figure 2: Agarose gel electrophoresis image of genomic DNA.

Lane M: $\lambda$ Hind III ${ }^{\mathrm{TM}}$ Marker in bp; Lane 1 is AQ5-03 Genomic DNA (23130 bp). 


\section{POLYMERASE CHAIN REACTION (PCR)}

The genomic DNA from isolates AQ5-02, AQ5-03 and AQ5-04 were used as the template for the 16S rDNA amplification. The primer used is based on reports of the highly conserved region for all bacteria as they completely amplified the 16S rRNA region of the gene corresponding to $1500 \mathrm{bp}$ (Acinas et al., 1997). The amplified 16S rRNA gene of the three isolates results to fragments with an estimated size of about $1500 \mathrm{bp}$ as shown in Figure 3.

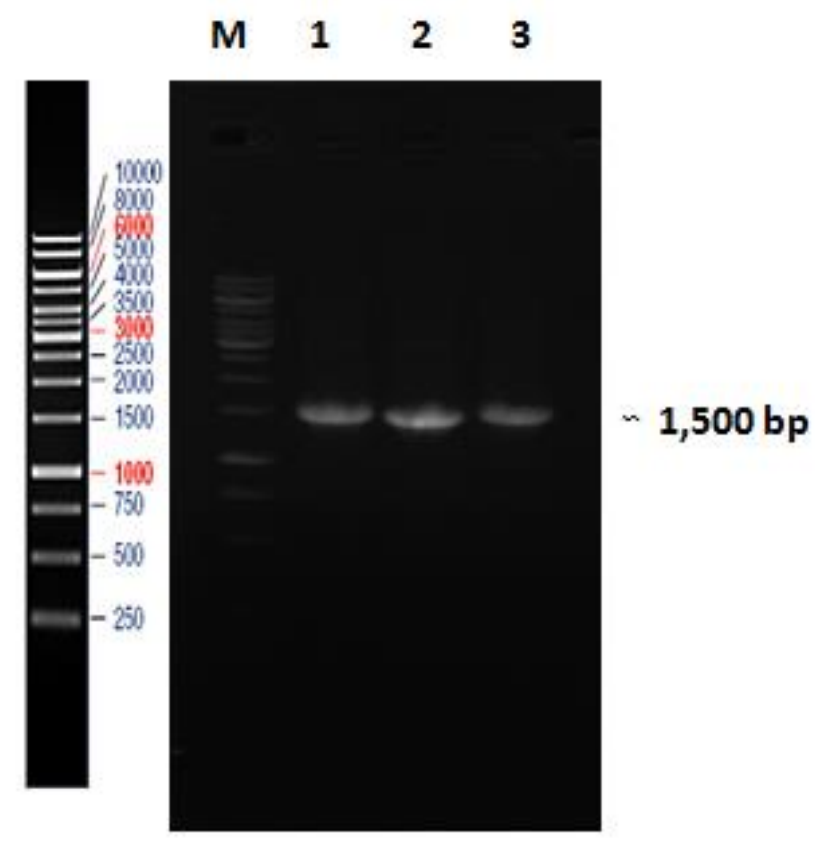

Figure 3: PCR product of 16S rRNA gene of isolate AQ5-02, AQ5-03, and AQ5-04.

Lane M: GeneRuler $1 \mathrm{~kb}$ DNA Ladder markers in bp: Lane 1,2 and 3 AQ5 -03 PCR product (1500 bp).

\section{S rRNA GENE SEQUENCING}

The 16S rRNA gene has some exceptionally conserved regions treasured for attaining decent sequence alignment. The resultant 1352 bases for the isolate AQ5-03 was compared with the available 16S sequences at the NCBI GeneBank database utilizing the blast server (http://www.ncbi.nlm.nih.gov/BLAST). This analysis clarifies that the sequence of the isolate AQ5-03 is closely related to Serratia species (Tables 1) 
Table 1: Foremost ten sequences producing the best alignment with Serratia sp. AQ5-03 from NCBI blast.

\begin{tabular}{cccccc}
\hline $\begin{array}{c}\text { Accession } \\
\text { Number }\end{array}$ & Max Score & Total Score & Query Cover & E-value & Identity \\
\hline NR044385 & 2352 & 2352 & $100 \%$ & 0 & $98 \%$ \\
NR036886 & 2351 & 2351 & $100 \%$ & 0 & $98 \%$ \\
NR114043 & 2340 & 2340 & $100 \%$ & 0 & $98 \%$ \\
NR113236 & 2338 & 2338 & $100 \%$ & 0 & $98 \%$ \\
NR041980 & 2329 & 2329 & $100 \%$ & 0 & $98 \%$ \\
NR042356 & 2246 & 2246 & $100 \%$ & 0 & $97 \%$ \\
NR041979 & 2230 & 2230 & $100 \%$ & 0 & $97 \%$ \\
NR025338 & 2228 & 2228 & $99 \%$ & 0 & $97 \%$ \\
NR112005 & 2226 & 2226 & $100 \%$ & 0 & $97 \%$ \\
NR037110 & 2224 & 2224 & $100 \%$ & 0 & $97 \%$ \\
\hline
\end{tabular}

\section{PHYLOGENETIC TREE FOR Serratia sp. AQ5-03}

The phylogenetic relationships between Serratia sp. strain AQ5-03 sp. and other related species of the Serratia genus constructed using their 16S rRNA gene sequences shows that the closest relative of strain AQ5-03 is Serratia marcescens with 95\% 16S rRNA sequence similarity (Figure 4). 


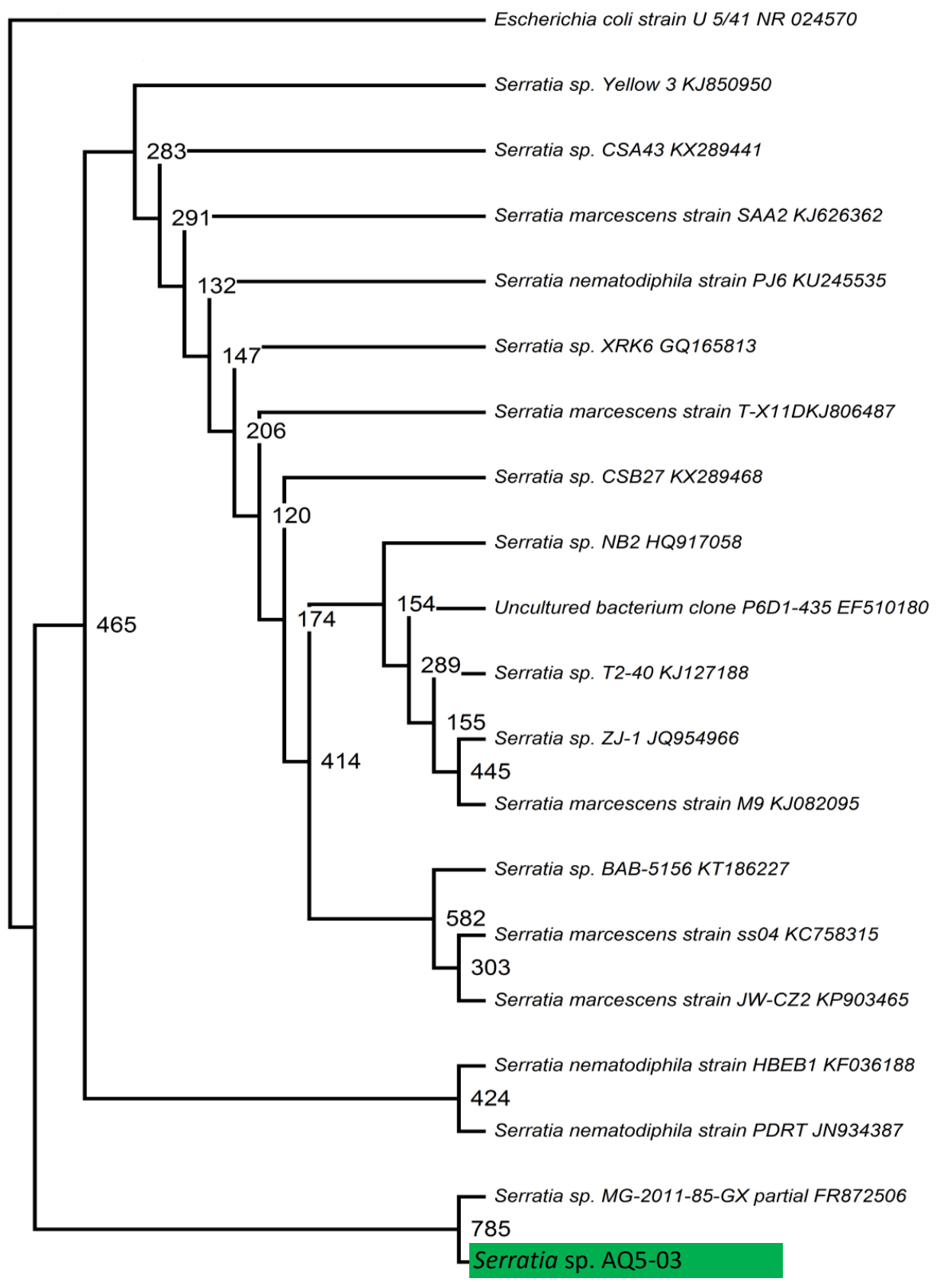

Figure 4: Phylogenetic tree showing the position of Serratia sp. AQ5-03 strain among Serratia genera and other bacteria.

\section{EFFECT OF TEMPERATURE}

As shown in Figure 5, the highest percentage of phenol degradation was between the temperatures of 30 and $35^{\circ} \mathrm{C}$, where more than $90 \%$ of degradation was achieved. 


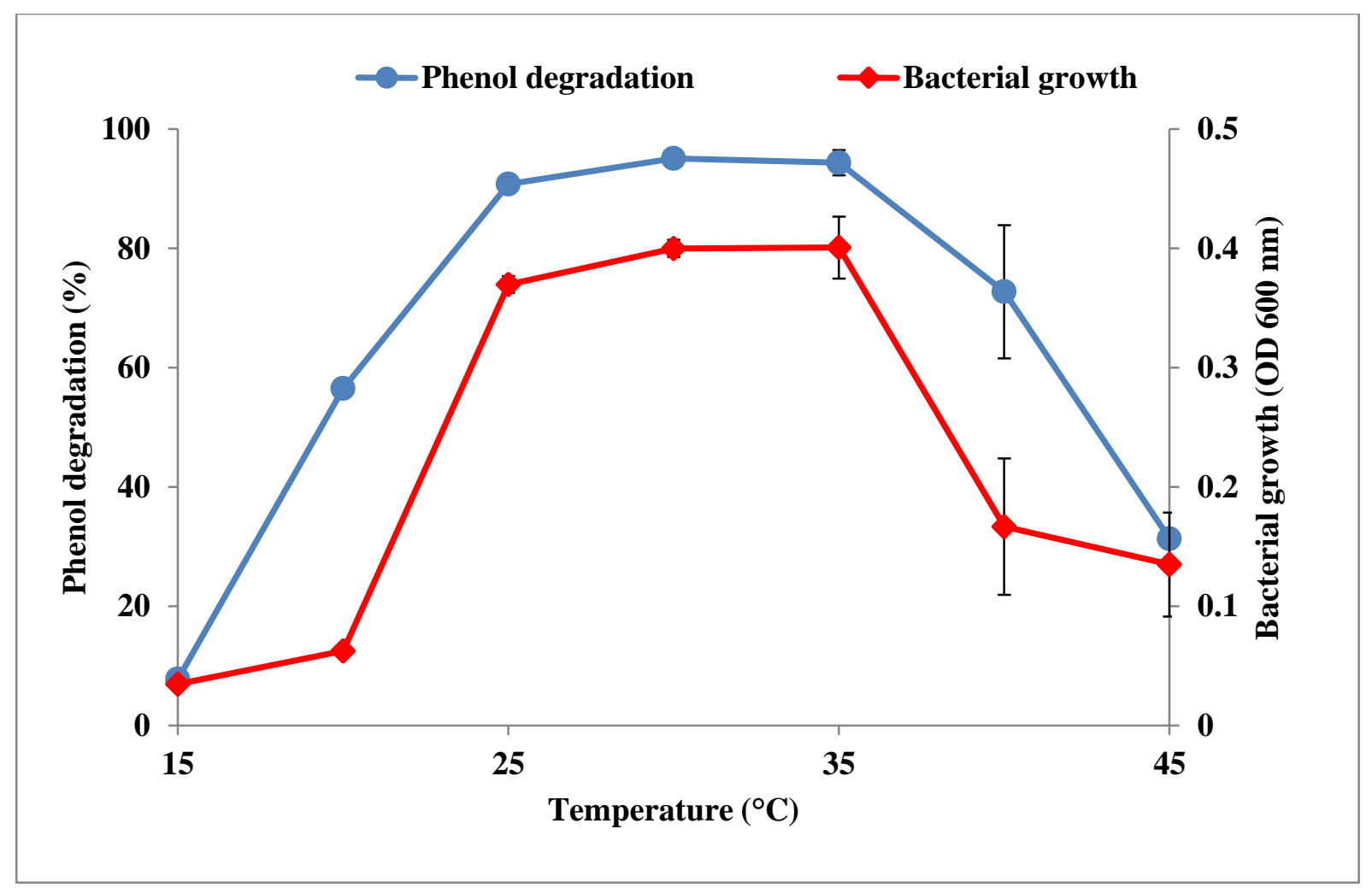

Figure 5: Effect of temperature on phenol degradation bacterial growth by Alcaligenes sp. Serratia sp. AQ5-03 


\section{EFFECT OF DIFFERENT BUFFERS ADJUSTED TO DIFFERENT $p H$ ON PHENOL DEGRADATION AND BACTERIAL GROWTH Serratia sp. AQ5-03 AND PHENOL DEGRADATION}

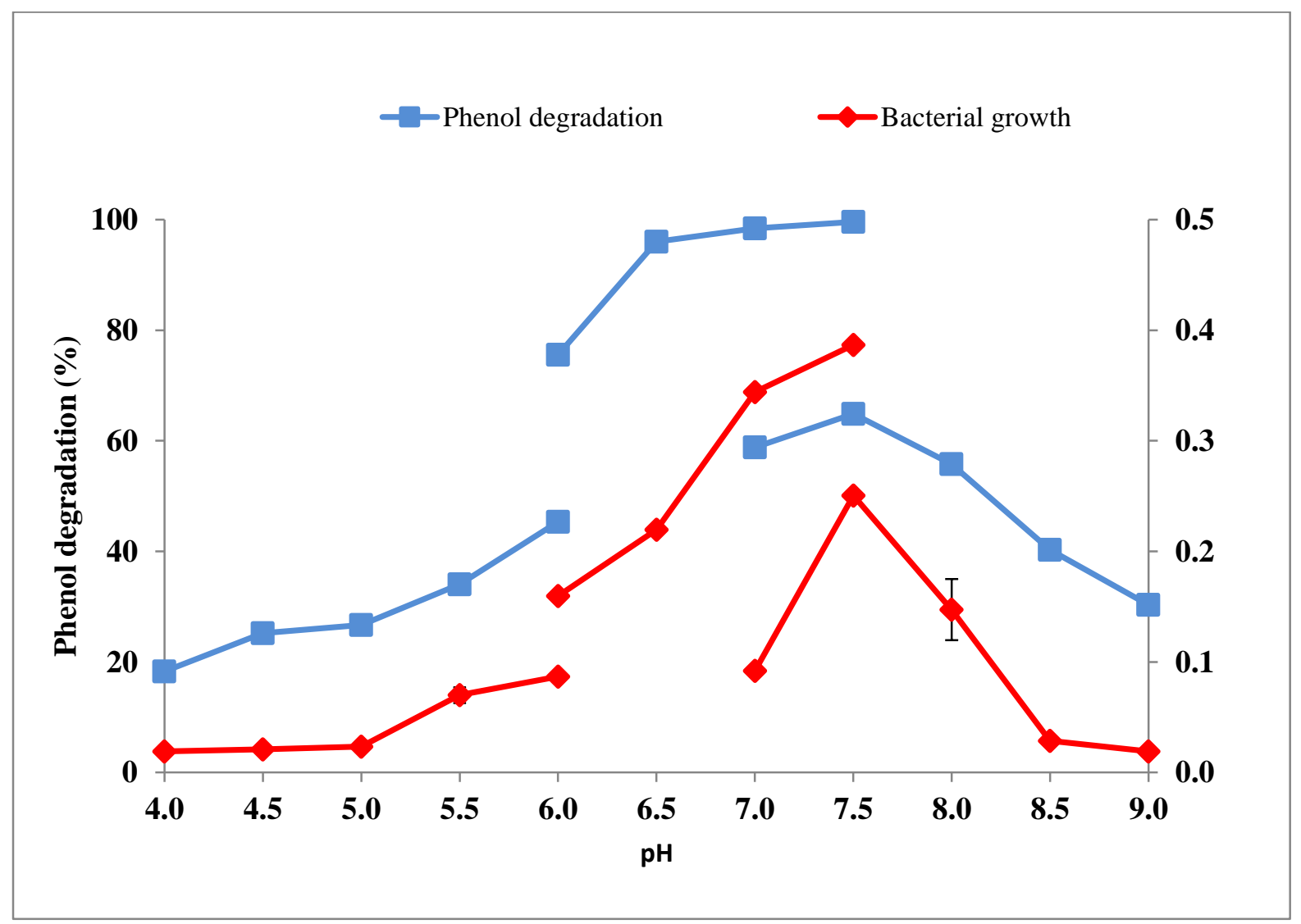

Figure 6: Effect of different buffers adjusted to different pHs on phenol degradation and bacterial growth by Serratia sp. AQ5-

03.

\section{DISCUSSION}

Neighbor-joining algorithm of phylogenetic analysis ascertained that the strain belonged to the Serratia sp. The evolutionary history was concluded using the Neighbour-Joining Technique (Saitou and Nei, 1987). The optimal tree with a sum of branch length $=40.34932914$ was presented. The percentage of replicate trees in which the related taxa were clustered together in the bootstrap trial (1000 replicates) was revealed next to the branches (Felsentein, 1985). The tree was drawn to scale, with branch distances in the same pieces as those of the evolutionary distances used to deduce the phylogenetic tree. The evolutionary reserves were calculated using the Maximum Composite Likelihood method (Koichiro et al., 2004) in the unit of quantity of base substitutions per site. Evolutionary analyses were conducted in PHYLIP (Tamura et al., 2013). E.coli strain 5/41 was used as the outgroup. Species names of bacteria were followed by their accession numbers. Bootstrap values were calculated based on 1000 resamplings.

Although there are reports of some bacteria that can degrade phenol at temperatures higher than $45{ }^{\circ} \mathrm{C}$, the most widely reported range is between 25 and $35^{\circ} \mathrm{C}$, which is an ideal range for most of the bioremediation processes especially in the tropical region. Using the Tukey-Kramer Multiple Comparisons Test for Serratia sp AQ5-03, there 
was no significant difference ( $p>0.05$ ) between 25 and $35{ }^{\circ} \mathrm{C}$, but there is a significant difference between 25 and 40 ${ }^{\circ} \mathrm{C}(\mathrm{p}<0.001)$. Temperature affects general metabolic processes according to the Arrhenius where a double increase in the rate of degradation and growth is anticipated at a temperature increase of $10{ }^{\circ} \mathrm{C}$. Very high temperatures denature enzymes and protein and are the cause of cessation of degradation and bacterial growth, respectively. On the other extreme, low-temperature phenol degradation has been reported (Kotturi et al., 1991; Li, et al., 2010) while thermophilic phenol degradation has also been reported with degradation observed at temperatures as high as $70{ }^{\circ} \mathrm{C}$ (Chen et al., 2008; Mutzel et al., 1996).

Studies on the effect of temperature on the optimal growth for all the isolates showed that the optimum points were achieved within the temperature range of $25-35^{\circ} \mathrm{C}$ (Figure 5). This indicates that the isolate grows best within the same range with most of the reported mesophilic bacteria (Bakhshi et al., 2011; Ahmad et al., 2012; Norazah et al., 2016). There was a decline in the bacterial growth at both of the extreme temperatures. Also, ANOVA analysis showed that there is a significantly difference $(\mathrm{p}<0.001)$ between 25 and $40{ }^{\circ} \mathrm{C}$ when to compare between 30 and 35 ${ }^{\circ} \mathrm{C}$ for the Serratia sp. AQ5-03 but no significant difference between 30 and $35^{\circ} \mathrm{C}(\mathrm{p}>0.005)$. Higher temperatures inhibit the growth of all the three bacteria this may be due to the denaturation of some key proteins which mediates the proper growth of microorganisms. The optimal temperature ranges revealed by this bacterial growth is suitable for use in temperate regions.

Among the factors that affect bioremediation, $\mathrm{pH}$ is one of importance. Thus, maintenance of $\mathrm{pH}$ in mineral salt media is very vital since $\mathrm{pH}$ affects bacterial physiological and biochemical activities which influences the growth and proliferation of bacteria. In this study, an overlapping buffering system comprising of acetate, phosphate, and Tris- $\mathrm{HCl}$ ranging from 4.0 to 9.0 were tested (Yadzir et al., 2016). A low bacterial growth and percentage phenol degradation were recorded for all the three isolates at highly acidic values. Also at high alkaline $\mathrm{pH}$, low degradation, and bacterial growth were observed. Figure 6 illustrated a healthy bacterial growth and phenol degradation by isolate AQ5-03 using phosphate buffer as the best buffering system for that particular experiment. The isolate degrades 0.5 $\mathrm{g} / \mathrm{L}$ phenol at $\mathrm{pH}$ range of 6.5 to 7.5 with a very shape decline in both growth and phenol degradation capacity at $\mathrm{pH}$ 8 and above. At acidic pHs of from 4.0 to 5.5 (acetate buffer), there were minimum growth and degradation rates. Most microorganisms used for phenol bioremediation have a preference for a neutral or near neutral $\mathrm{pH}$ for effective phenol degradation. Many phenol-degrading bacteria shared optimal $\mathrm{pH}$ as shown in this study, such as Bacillus cereus at pH 7.0, Pseudomonas putida MTCC 1194 pH 7.1 (Kumar et al.,2005), Acinetobacter sp. strain PD12 pH 7.2 (Zhang et al., 2007), Alcaligenes faecalis at $\mathrm{pH} 7.2$ (Jiang et al., 2007), Rhodococcus UKM-P at pH 7.5 (Suhaila et al.,2013a), Ewingella Americana at pH 7.5 (Khleifat, 2006). However, there are few reports of some bacteria that degrade phenol outside the $\mathrm{pH}$ range of 6.5 to 7.5 such as Pseudomonas putida ATCC that grows and degrades phenol at $\mathrm{pH}$ of 5.5 to 6.0 (Mordocco et al.,1999) and also Ochrobactrum sp. at the optimum pH of 8.0 (Kiliç, 2009). Halomonas campisalis is able to mineralised phenol within the pH range of 8.0 to 11 (Alva and Peyton, 2003). An optimum $\mathrm{pH}$ is favourable for phenol degrading enzymes, and it enhances the stability and the affinity of the enzymes towards the substrates. 


\section{CONCLUSION}

Phenol degrading bacteria isolate AQ5-03 was identified as Serratia sp. AQ5-03 using Gram staining technique and 16S rRNA sequencing. The sequence has been deposited in Genbank with accession number KT693287. Optimisation for the best phenol biodegradation conditions was conducted by One Factor at a Time (OFAT) approach. Serratia sp. AQ5-03 is a good candidate for further research in bioremediation.

\section{REFERENCES}

Acinas, S. G., Rodríguez-Valera, F., and Pedrós-Alió, C. (1997). Spatial and temporal variation in marine bacterioplankton diversity as shown by RFLP fingerprinting of PCR amplified 16S rDNA. FEMS Microbiology Ecology, 24(1), 27-40.

Aghalino, S. O., and Eyinla, B. (2009). Oil Exploitation and Marine Pollution: Evidence from the Niger Delta, Nigeria. Journal of Human Ecology, 28(3), 177-182.

Ahmad, S. A., Shamaan, N. A., Arif, N. M., Koon, G. B., Shukor, M. Y. A., and Syed, M. A. (2012). Enhanced phenol degradation by immobilized Acinetobacter sp. strain AQ5NOL 1. World Journal of Microbiology and Biotechnology, 28(1), 347-352. https://doi.org/10.1007/s11274-011-0826-Z

Ahmad, S. A., Syed, M. A., Arif, N. M., Yunus, M., Shukor, A., and Shamaan, A. (2011). Isolation, Identification and Characterization of Elevated Phenol Degrading Acinetobacter sp. Strain AQ5NOL 1. Australian Journal of Basic and Applied Sciences, 5(8), 1035-1045.

Ali, N., Hameed, A., and Ahmed, S. (2009). Physicochemical characterization and Bioremediation perspective of textile effluent, dyes and metals by indigenous Bacteria. Journal of Hazardous Materials, 164, 322-328. https://doi.org/10.1016/j.jhazmat.2008.08.006

Alva, V. A., and Peyton, B. M. (2003). Phenol and catechol biodegradation by the haloalkaliphile Halomonas campisalis Influence of $\mathrm{pH}$ and salinity. Environmental Science and Technology, 37(19), 4397-4402. https://doi.org/10.1021/es0341844

Arif, N. M., Ahmad, S. A., Syed, M. A., and Shukor, M. Y. (2013). Isolation and characterization of a phenoldegrading Rhodococcus sp. strain AQ5NOL 2 KCTC 11961BP. Journal of Basic Microbiology, 53(1), 9-19. https://doi.org/10.1002/jobm.201100120

Arutchelvan, V., Kanakasabai, V., Elangovan, R., Nagarajan, S., and Muralikrishnan, V. (2006). Kinetics of high strength phenol degradation using Bacillus brevis. Journal of Hazardous Materials, 129(1-3), 216-222. https://doi.org/10.1016/j.jhazmat.2005.08.040

Bakhshi, Z., Najafpour, G., Kariminezhad, E., Pishgar, R., Mousavi, N., and Taghizade, T. (2011). Growth kinetic models for phenol biodegradation in a batch culture of Pseudomonas putida. Environmental Technology, 32(16), 1835-1841. https://doi.org/10.1080/09593330.2011.562925

Brook, R. D., Franklin, B., Cascio, W., Hong, Y., Howard, G., Lipsett, M., ... Tager, I. (2004). Air pollution and cardiovascular disease: A statement for healthcare professionals from the expert panel on population and prevention science of the American Heart Association. Circulation, 109(21), 2655-2671. https://doi.org/10.1161/01.CIR.0000128587.30041.C8 
Chen, C.-L., Wu, J.-H., and Liu, W.-T. (2008). Identification of important microbial populations in the mesophilic and thermophilic phenol-degrading methanogenic consortia. Water Research, 42(8-9), 1963-1976. https://doi.org/10.1016/j.watres.2007.11.037

Demoling, L. A., and Bååth, E. (2008). No Long-Term Persistence of Bacterial Pollution-Induced Community Tolerance in Tylosin-Polluted Soil, 42(18), 6917-6921.

Desai, C., Pathak, H., and Madamwar, D. (2010). Advances in molecular and '-omics' technologies to gauge microbial communities and bioremediation at xenobiotic/anthropogen contaminated sites. Bioresource Technology, 101(6), 1558-1569. https://doi.org/10.1016/j.biortech.2009.10.080

DOE, 2009. Malaysia Environmental Quality Report 2008. Department of Environment, Ministry of Natural Resources and Environment, Malaysia.

Felsenstein, J. (1985). Confidence limits on phylogenies: An approach using the bootstrap. Evolution, 39, 783-791.

Felsenstein, J. (1992). Estimating effective population size from samples of sequences: A bootstrap Monte Carlo integration method. Genetical Research, 60(3), 209-220.

Felsentein J. (1985). Confidence Limits on Phylogenies: An Approach Using the Bootstrap Author ( s ): Joseph Felsenstein Stable URL : http://www.jstor.org/stable/2408678 . Evolution, 39(4), 783-791.

Fereidoun, H., Nourddin, M. S., Rreza, N. A., Ahmad, R., and Pouria, H. (2007). the Effect of Long-Term Exposure To Particulate Pollution on the Lung Function of Teheranian and Zanjanian Students. Pakistan Journal of Physiology, 3(2).

González, P. S., Capozucca, C. E., Tigier, H. A., Milrad, S. R., and Agostini, E. (2006). Phytoremediation of phenol from wastewater, by peroxidases of tomato hairy root cultures. Enzyme and Microbial Technology, 39(4), 647-653. https://doi.org/10.1016/j.enzmictec.2005.11.014

Hossain, M. A., Salehuddin, S., Hanif, M., Kundu, P. K., and others. (2009). Carcinogenic polycyclic aromatic hydrocarbon (PAH), anthracene in cabbage samples from Bangladesh. Asian Journal of Food and AgroIndustry, 2(3), 315-320.

Bai, J., Jiang, Y., Wen, Jia, X., and Hu, Z. (2007). Biodegradation of phenol at high initial concentration by Alcaligenes faecalis. Journal of Hazardous $\quad$ Materials, $147(1-2), \quad 672-676$. https://doi.org/10.1016/j.jhazmat.2007.05.031

Jukes, T. H., and Cantor, C. R. (1969). Evolution of protein molecules. Mammalian Protein Metabolism, $21-132$.

Karamba, K. I., Shukor, M. Y., Syed, M. A., Zulkharnain, A., and Adeela, N. (2015). Isolation, screening and characterization of cyanide-degrading Serratia marcescens strain AQ07. Journal of Chemical and Pharmaceutical Sciences, 8(2), 401-406.

Khleifat, K. M. (2006). Biodegradation of phenol by Ewingella americana : Effect of carbon starvation and some growth conditions. Process Biochemistry, 41(9), 2010-2016. https://doi.org/10.1016/j.procbio.2006.04.015

Kiliç, N. K. (2009). Enhancement of phenol biodegradation by Ochrobactrum sp. isolated from industrial wastewaters. International Biodeterioration and Biodegradation, 63(6), 781. https://doi.org/10.1016/j.ibiod.2009.06.006

Kimura, M. (1980). A Simple Method for Estimating Evolutionary Rates of Base Substitutions Through Comparative 
Studies of Nucleotide Sequences. Journal of Molecular Evolution, 16(1330), 111-120. https://doi.org/10.1007/BF01731581

Kishino, H., and Hasegawa, M. (1989). Evaluation of the maximum likelihood estimate of the evolutionary tree topologies from DNA sequence data, and the branching order in hominoidea. Journal of Molecular Evolution, 29(2), 170-179. https://doi.org/10.1007/BF02100115

Ko, F. W. S., and Hui, D. S. C. (2010). Effects of Air Pollution on Lung Health. Clinical Pulmonary Medicine, 17(6), 300-304. https://doi.org/10.1097/CPM.0b013e3181fa1555

Kotturi, G., Robinson, C. W., and Inniss, W. E. (1991). Phenol degradation by a psychrotrophic strain of Pseudomonas putida. Applied Microbiology and Biotechnology, 34(4), 539-543.

Kumar, A., Shashi, K., and Surendra, K. (2005). Biodegradation kinetics of phenol and catechol using Pseudomonas putida MTCC 1194. Biochemical Engineering Journal, 22, 151-159. https://doi.org/10.1016/j.bej.2004.09.006

Li, Y., Li, J., Wang, C., and Wang, P. (2010). Growth kinetics and phenol biodegradation of psychrotrophic

Pseudomonas putida LY1. Bioresource Technology, 101(17), 6740-6744. https://doi.org/10.1016/j.biortech.2010.03.083

Lockhart, P. J., Steel, M. A., Hendy, M. D., and Penny, D. (1994). Recovering evolutionary trees under a more realistic model of sequence evolution. Molecular Biology and Evolution, 11(4), 605-612. https://doi.org/desktop

Luo, Z.-H., Pang, K.-L., Gu, J.-D., Chow, R. K. K., and Vrijmoed, L. L. P. (2009). Degradability of the three dimethyl phthalate isomer esters (DMPEs) by a Fusarium species isolated from mangrove sediment. Marine Pollution Bulletin, 58(5), 765-768. https://doi.org/10.1016/j.marpolbul.2009.03.005

Luo, Z.-H., Wu, Y.-R., Pang, K.-L., Gu, J.-D., and Vrijmoed, L. L. P. (2011). Comparison of initial hydrolysis of the three dimethyl phthalate esters (DMPEs) by a basidiomycetous yeast, Trichosporon DMI-5-1, from coastal sediment. Environmental Science and Pollution Research International, 18(9), 1653-1660. https://doi.org/10.1007/s11356-011-0525-1

Margesin, R., Fonteyne, P. A., and Redl, B. (2005). Low-temperature biodegradation of high amounts of phenol by Rhodococcus spp. and basidiomycetous yeasts. Research in Microbiology, 156(1), 68-75. https://doi.org/10.1016/j.resmic.2004.08.002

Margush, T., and McMorris, F. R. (1981). Consensus n-trees. Bulletin of Mathematical Biology, 43(2), 239-244. https://doi.org/10.1007/BF02459446

Matkin, C. O., Saulitis, E. L., Ellis, G. M., Olesiuk, P. and Rice, S. D. (2008). Ongoing population-level impacts on killer whales Orcinus orca following the 'Exxon Valdez' oil spill in Prince William Sound, Alaska. Marine Ecology Progress Series, 356(1983), 269-281. https://doi.org/10.3354/meps07273

Mordocco, A., Kuek, C., and Jenkins, R. (1999). Continuous degradation of phenol at low concentration using immobilized Pseudomonas putida. Enzyme and Microbial Technology, 25, 530-536.

Mutzel, A., Reinscheid, U. M., Antranikian, G., and MuÈller, R. (1996). Isolation and characterization of a thermophilic bacillus strain, that degrades phenol and cresols as sole carbon source at $70^{\circ} \mathrm{C}$. Appl Microbiol Biotechnology, 593-596. 
Norazah, M.., Ahmad, S. A., Shukor, M. Y., Arif, N. M., Khalilah, A.., and Abdul Latif, I. (2016). Statistical optimization for improvement of phenol degradation by Rhodococcus sp. NAM 81. Journal of Environmental Biology, 37(May), 355-360.

Page, R. (1996). TREEVIEW: An application to display phylogenetic trees on personal computers. Computer Applications in Biosciences, 12, 357-358.

Pradeep, N. V., Anupama, S., Navya, K., Shalini, H. N., Idris, M., and Hampannavar, U. S. (2015). Biological removal of phenol from wastewaters: a mini review. Applied Water Science, 5(2), $105-112$. https://doi.org/10.1007/s13201-014-0176-8

Saitou, N., and Nei, M. (1987). The neighbor-joining method: a new method for reconstructing phylogenetic trees. Molecular Biology and Evolution, 4(4), 406-425.

Suhaila, Y. N., Rosfarizan, M., Ahmad, S. A., Latif, I. A., and Ariff, A. B. (2013a). Journal of Environmental Biology Nutrients and culture conditions requirements for the degradation of phenol by Rhodococcus UKMP-5M. Journal of Environmental Biology, 34(May), 635-643.

Suhaila, Y. N., Rosfarizan, M., Ahmad, S. A., Latif, I. A., and Ariff, A. Bin. (2013b). Journal of Environmental Biology Nutrients and culture conditions requirements for the degradation of phenol by Rhodococcus UKMP-5M. Journal of Environmental Biology, 34(May), 635-643.

Tamura, K., Nei, M., and Kumar, S. (2004). Prospects for inferring very large phylogenies by using the neighborjoining method. Proceedings of the National Academy of Sciences of the United States of America, 101(30), 11030-11035. https://doi.org/10.1073/pnas.0404206101

Tamura, K., Stecher, G., Peterson, D., Filipski, A., and Kumar, S. (2013). MEGA6: Molecular Evolutionary Genetics Analysis Version 6.0. Molecular Biology and Evolution, 30(12), 2725-2729. https://doi.org/10.1093/molbev/mst197

Yadzir, Z. H. M., Shukor, M. Y., Ahmad, A., Nazir, M. S., Shah, S. M. U., and Abdullah, M. A. (2016). Phenol removal by newly isolated Acinetobacter baumannii strain Serdang 1 in a packed-bed column reactor. Desalination and Water Treatment, 57(28), 13307-13317. https://doi.org/10.1080/19443994.2015.1063459

Zeng, L., Huang, J., Zhang, Y., Qiu, G., Tong, J., Chen, D., ... Luo, X. (2008). An effective method of DNA extraction for bioleaching bacteria from acid mine drainage. Applied Microbiology and Biotechnology, 79(5), 881-888.

Zhang, L., Wu, W., and Wang, J. (2007). Immobilization of activated sludge using improved polyvinyl alcohol (PVA) gel. Journal of Environmental Sciences (China 